\title{
Social and environmental aspects of family farming at Cacoal City, Rondônia State, Brazil
}

\author{
Aurélio Ferreira Borges ${ }^{1 *}$, Edmar da Costa Alves ${ }^{1}$, Maria dos Anjos Cunha Silva Borges ${ }^{1}$, \\ Sérgio Nunes de Jesus ${ }^{1}$, Jessé Alves Batista ${ }^{1}$ and José Luiz Pereira de Rezende ${ }^{2}$ \\ ${ }^{1}$ Federal Institute of Education in Rondônia State, Brazil. \\ ${ }^{2}$ Federal University of Lavras, Brazil.
}

Received 14 October, 2013; Accepted 4 August, 2014

\begin{abstract}
This study aimed to evaluate social and environmental aspects of family farming at Cacoal City, Rondonia State, in Brazil. This is applied in non-experimental (descriptive) research. Questionnaire was designed as the main tool of the study. Eleven (11) semi-structured interviews were conducted with family farmers from eleven cooperative associations. Quantitative and qualitative approaches were employed in the scientific research, using a questionnaire consisting of twenty four questions that sought to evaluate environmental aspects of the sample of family farmers. It was concluded that agriculture continues to be basis of the local development and rurality model found in the Western Amazon Brazil.
\end{abstract}

Key words: Social and environmental, family farming, Western Amazon.

\section{INTRODUCTION}

In developing countries, more than half of the population lives in rural areas, often in situation of extreme poverty. According to CEPAL (2012), in 2010 there were 180 million poor in the region, receiving less than two U.S. dollars per day, of which more than 71 million lived in extreme poverty, earning less than one U.S. dollar per day. The total rural population of the region reached 141 million people, 20 million more than in 1999, of which 75 million were poor and almost 40 million lived in extreme poverty.

Rural development is defined as a localized process of social change and sustainable economic growth, which aims at the constant improvement of the rural community and of each individual integrated in it (Anguita and Azcona, 2007). The territorial organization is an essential tool to delineate rural development. Liberalism, spontaneous evolution driven by the laws of the market and by economic interest groups can hardly ensure the implementation of sustainability criteria that should be required of the rural territory.

According to Márquez (2001), rural development is the process of economic development and structural change to improve the living conditions of the local population inhabiting a given space. The author identifies three dimensions to rural development: the economic, the socio-cultural and the political administrative. Through this process, it seeks to improve the conditions of life and work that enables the creation of employment and income that is compatible with the preservation of the environment and the sustainable use of natural resources.

According to these authors, in Latin America and 


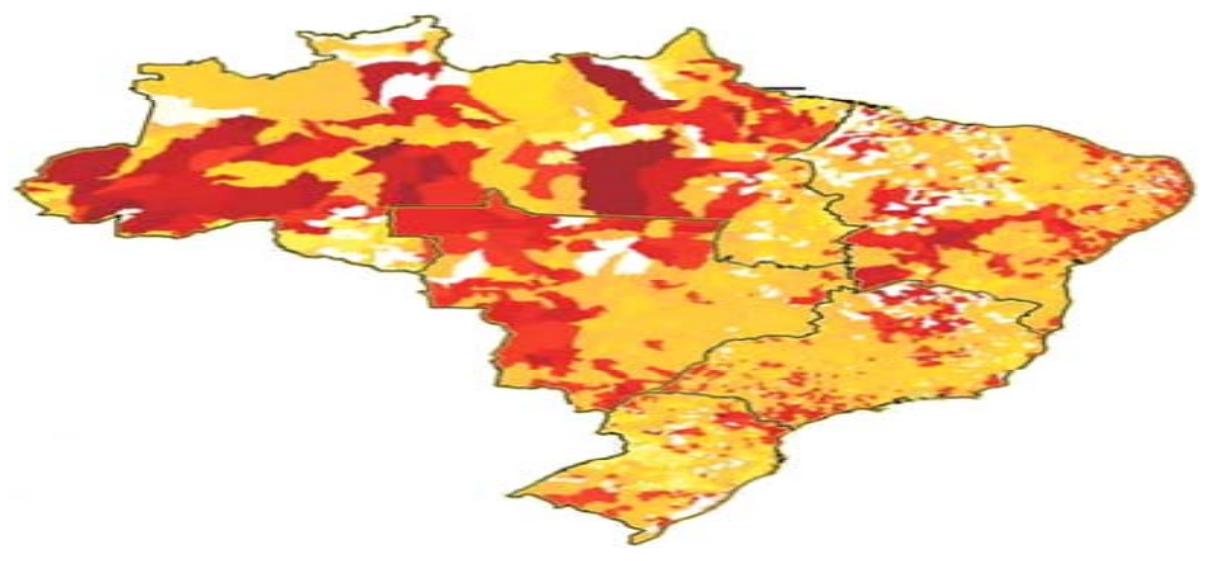

INDEX VALUE

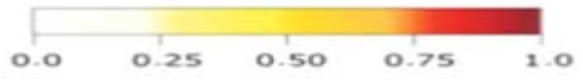

Figure 1. Gini-land index in Brazil. Source: Barreto and Sparovek (2005).

Caribbean this rural population is characterized as one who cultivates marginal lands mostly dry, which lacks of sufficient knowledge to be able to read and write, whose families are numerous and suffer from high rates of mortality. This segment of the population is composed of smallholders dependent on rainfall, landless workers, indigenous peoples and tribes. This situation of rural poverty causes massive degradation of local natural resources.

According to Guanziroli et al. (2009), the peculiarities of agricultural production shorten the economies of scale, superiority occurrence in massive industrial company, in analogy to the small and medium enterprise. The benefits from production on a large-scale are abbreviated by adopting cooperative forms of production and trade. The farmers have advantages in the management of working efficiency, pronounced in intensive production that requires careful cultivation, which cannot be compensated by the firm employer. Even paying higher wages, it is difficult to get the waged proletarian the productivity achieved by a family who works for themselves.

According to Hoffman and Ney (2010), there is a contrast in the high concentration of land ownership in Brazil, which has updated Gini-land index average of 0.86 . The Gini-land index has theoretical foundation in the Lorenz curve, as the quotient between the area of inequality $(\alpha)$ and the value of this limit: Gini-land $=\alpha / 0.5$ $=2 \alpha$. This curve characterizes the inequality of a distribution. The Gini-land index can vary from 0 to 1 . At 0 , there is no inequality (land ownership is equally distributed to all individuals). At 1 , the inequality is at a maximum (only one individual has possession of all the land available) (Waquil and Mattos, 2002).

In order to meet the demand of the Ministry of Agrarian
Development, the Agricultural Census (IBGE, 2006) adopted the concept of family agriculture, according to Law number 11,326, from 24 July, 2006 (BRAZIL, 2006) which establishes guidelines for the formulation of the National Policy for Family Agriculture and Rural Family Enterprises.

In Law number 11,326 , family farming was defined as follows: Article 3 - For the purposes of this Act, family farmer and rural family entrepreneur is one who practices activities in rural areas, serving both the following requirements:

1) Does not hold, in any capacity, greater than four (4) fiscal modules area.

2) Use predominantly labor of your own family in the economic activities of your establishment or enterprise.

3) Has predominantly household income originated from economic activities linked to the establishment itself or enterprise.

4) Drive your establishment or enterprise with your family.

In Brazil, family farmers, who use at least $50 \%$ of labor from their own families, operate about $85.2 \%$ of agricultural establishments. Family farming occupies $30.5 \%$ of agricultural lands, but accounts for $37.9 \%$ of Brazilian agricultural production. Family farming, commonly associated with outdated forms and production for subsistence, is in the essence of the modern Brazilian agribusiness, accounting for $31.6 \%$ of soybean production, $39.9 \%$ of poultry production and $48.6 \%$ of corn production (Guanziroli et al., 2009). The Gini-land index for Cacoal is currently ranging from 0.25 to 0.50 (Figure 1).

Conforms to Buainain et al. (2003), in Brazil, $39.8 \%$ of family farms have less than 5 ha, $30 \%$ are between 5 and 
20 ha and $17 \%$ are in the range of 20 and 50 ha. Family farmers with an area greater than 100 ha and less than the maximum regional area represents only $5.9 \%$ of establishments which occupy $44.7 \%$ of the entire area of the Brazilian family farming.

The aim of this study was to evaluate social and environmental aspects of family farming in Cacoal City, Rondonia State. The research problem arose from the question: What are the environmental characteristics of the family farming at Cacoal City, Rondonia State, Brazil?

\section{MATERIALS AND METHODS}

Cacoal is Brazilian municipality located in the Rondonia State, distant $479 \mathrm{~km}$ from the capital Porto Velho, located in the central region. It is located at latitude $11^{\circ} 26^{\prime} 19^{\prime \prime}$ south and longitude $61^{\circ} 26^{\prime} 50^{\prime \prime}$ west, with an altitude of $200 \mathrm{~m}$. Its estimated population in IBGE (2010) was around 78,958 inhabitants. It has an area of $13,792.638 \mathrm{~km}^{2}$. The climate is hot and humid, with annual average temperature of $34^{\circ} \mathrm{C}$. The annual average precipitation ranges from 1,750 to $2,750 \mathrm{~mm}$ annually.

This is applied in non-experimental (descriptive) research. The methodology of research is survey because the main purpose of the researcher is identifying the social and environmental aspects of family farming in Cacoal City, Rondônia State, in Brazil. Questionnaire was designed as the main tool of the study. All questions except the personal characteristics of family farmers were written as five-point Likert scale. In addition to questionnaires, observations and interviews were also used.

The case study was conducted in a sample of family farmers from eleven cooperative associations of Cacoal, central Rondonia, in Brazil. Semi-structured interviews were conducted, consisting of theoretical presuppositions descriptions of the qualitative and quantitative approach. We sought to observe, expose, analyze and correlate facts or phenomena. A questionnaire consisting of 24 questions that sought to evaluate socio-demographic and environmental aspects in the sample was used. Socio-demographic and socio-environmental variables evaluated age group, degree of literacy, agricultural activities of the farmers, family size, among others. All responses were analyzed statistically with support of the Statistical Package for the Social Sciences in its version 19.0 (Statistics, 2011). Data was analyzed using correlation coefficient of Spearman.

\section{RESULTS}

Spearman correlation coefficient was used to evaluate the relations between the family members of the family farming who worked in their property, agricultural technology by family farming consulted and trading of agricultural produce of family farmers with the age of family farmers.

The results obtained show that there is a statistically significant, negative relationship between the family members of the family farming who worked in their property $(r=-0.809, p$ (two-tailed $<0.01)$ agricultural technology by family farming consulted $(r=-0.795, p$ (two-tailed $<0.01$ ) and trading of agricultural produce of family farming $(r=-0.684, p$ (two-tailed $\leq 0.02)$ with the age of family farmers.
Two farmers $(18.2 \%$ of the sample) said that the monthly turnover of the property is a maximum of one minimum wage of $R \$ 724,00$ ( $\mathrm{U} \$ 324,00$ ). Five farmers $(45.5 \%)$ said that the monthly revenue ranges from 2 to 3 minimum wages. One farmer $(9.1 \%)$ said that the monthly revenue ranges from 3.1 to 4 minimum wages, a farmer $(9.1 \%)$ said that the monthly revenue ranges from 4.1 to 5 minimum wages and two farmers $(18.2 \%)$ said that the monthly revenue of the property is greater than 5.1 minimum wages (Table 1 ).

One farmer $(9.1 \%)$ said that the biggest challenge for the family farm is conquering the consumer market, two $(18.2 \%)$ said that the biggest challenge is getting rural credit, two $(18.2 \%)$ said keep the family on the farm, and six $(54.5 \%)$ said that the low financial return is the greatest challenge of family farming (Table 2 ).

Two farmers $(18.2 \%)$ said that the difficulties faced while selling the products are consumer requirements, one $(9.1 \%)$ said it is to get quality products and eight $(72.8 \%)$ said that value of the products is low (Table 3 ).

Five farmers $(45.5 \%)$ said that environmental technology most used on the farm is plowing the soil, two $(18.2 \%)$ said pasture rotation, two $(18.2 \%)$ said irrigation and two (18 $2 \%$ ) said production control (Table 4).

Eight farmers $(72.7 \%)$ said they contribute to the environment by preserving the legal reserves of the property, one $(9.1 \%)$ said by making crop rotation on the property, one $(9.1 \%)$ by maintaining the quality of water and one $(9.1 \%)$ said to contribute by practicing adequate soil management on the property (Table 5 ).

The data analysis of federal, state and local government programs offered to farmers showed that two producers $(18.2 \%)$ of the sample $(n=11)$ used the family grant, seven $(63.6 \%)$ used the National Program for Strengthening Family Agriculture (PRONAF) and two $(18.2 \%)$ producers said they did not use any government program (Table 6).

In Cacoal City, there is 5,924 family farmers, 82 families settled at program Agrarian reform in Brazil, five (5) fishermen and (1) an indigenous land (Table 7).

In the City, $69.86 \%$ of the properties have between 0.5 and 50 ha, and $6.07 \%$ over 200 ha. However, the mean areas of these major producers rotate around 917 ha (Table 8).

Due to the work of the National Institute of Colonization and Agrarian Reform in Brazil (INCRA), in the agrarian structure system of Rondônia State and Cacoal City, the State and this City currently have, on average, $25 \%$ of its land designated for small rural workers, $6 \%$ for public competition, $34 \%$ are areas of land regularization and $35 \%$ indigenous areas and conservation units.

\section{DISCUSSION}

In a research conducted by DIEESE (2011), about the distribution of the employed people in agriculture for 
Table 1. Monthly income of family farmers at Cacoal City, in 2011.

\begin{tabular}{ccc}
\hline Monthly income (minimum wage) & Number of farmers & Percentage (\%) \\
\hline 1 & 2 & 18.2 \\
$2-3$ & 5 & 45.5 \\
$3.1-4$ & 1 & 9.1 \\
$4.1-5$ & 1 & 9.1 \\
More than 5.1 & 2 & 18.2 \\
\hline
\end{tabular}

Source: Survey data using SPSS 19.0 software.

Table 2. Challenges of family farm according to producers from Cacoal, in 2011.

\begin{tabular}{lcc}
\hline Challenge & Number of producers & Percentage (\%) \\
\hline Conquering the consumer market & 1 & 9.1 \\
Getting rural credit & 2 & 18.2 \\
Family on the farm & 2 & 18.2 \\
Low financial return & 6 & 54.5 \\
\hline
\end{tabular}

Source: Survey data using SPSS 19.0 software.

Table 3. Difficulties faced while selling the products, Cacoal, in 2011.

\begin{tabular}{lcc}
\hline Difficulties while selling & Number of producers & Percentage (\%) \\
\hline Qonsumer requirements & 2 & 18.2 \\
Quality of the products & 1 & 9.1 \\
Low price & 8 & 72.8 \\
\hline
\end{tabular}

Source: Survey data using SPSS 19.0 software.

Table 4. Environmental technology most used on the farm, Cacoal, in 2011.

\begin{tabular}{lcc}
\hline Environmental technology & Number of producers & Percentage (\%) \\
\hline Plowing the soil & 5 & 45.5 \\
Pasture rotation & 2 & 18.2 \\
Irrigation & 2 & 18.2 \\
Production control & 2 & 18.2 \\
\hline
\end{tabular}

Source: Survey data using SPSS 19.0 software.

Table 5. Contributions to improve the environment in the property, Cacoal, in 2011.

\begin{tabular}{lcc}
\hline Environment contribution & Number of producers & Percentage (\%) \\
\hline Preserving the legal reserves & 8 & 72.7 \\
Crop rotation & 1 & 9.1 \\
Quality of the water & 1 & 9.1 \\
Soil management & 1 & 9.1 \\
\hline
\end{tabular}

Source: Survey data using SPSS 19.0 software.

income, by gender, it was found that $20.2 \%$ of men and $9.7 \%$ of women had average monthly income of half $(0.5)$ minimum wage, $25.2 \%$ of men and $6.8 \%$ of women had average monthly income ranging from 0.5 to 1 minimum 
Table 6. Government programs used by family farmers in Cacoal City, in 2011

\begin{tabular}{lcc}
\hline Govern problem & Number of producers & Percentage (\%) \\
\hline Family Grant & 2 & 18.2 \\
Pronaf & 7 & 63.6 \\
No government program & 2 & 18.2 \\
\hline
\end{tabular}

Source: Survey data using SPSS 19.0 software.

Table 7. Social demand in Cacoal City.

\begin{tabular}{lcccc}
\hline City & Family farmers & Settled family & Fishermen & Indigenous lands \\
\hline Cacoal & 5,924 & 82 & 5 & 1 \\
\hline Source: IBGE $(2006)$. & & &
\end{tabular}

Table 8. Agrarian structure of Cacoal City in 2011.

\begin{tabular}{|c|c|c|c|c|c|c|c|c|c|}
\hline City & Area group & $\begin{array}{l}\text { Up to } 20 \\
\text { ha }\end{array}$ & $\begin{array}{c}2.1 \text { to } 5.0 \\
\text { ha }\end{array}$ & $\begin{array}{c}5.1 \text { to } 10.0 \\
\text { ha }\end{array}$ & $\begin{array}{c}10.1 \text { to } 20.0 \\
\text { ha }\end{array}$ & $\begin{array}{c}20.1 \text { to } 50.0 \\
\text { ha }\end{array}$ & $\begin{array}{c}50.1 \text { to } 100.0 \\
\text { ha }\end{array}$ & $\begin{array}{c}100.1 \text { to } 200.0 \\
\text { ha }\end{array}$ & $\begin{array}{c}\text { More than } 200.0 \\
\text { ha }\end{array}$ \\
\hline \multirow{2}{*}{ Cacoal } & $\%$ & 2.75 & 23.10 & 11.40 & 11.65 & 20.96 & 16.84 & 7.24 & 6.07 \\
\hline & Mean area & 1.2 & 3.7 & 7.5 & 14.6 & 32.7 & 67.5 & 123.1 & 917.0 \\
\hline
\end{tabular}

Source: IBGE (2006).

wage, $7.8 \%$ of men and $1.1 \%$ of women had average monthly income of 2 to 5 minimum wages, $1.5 \%$ of men and $0.3 \%$ of women had average monthly income of 5 to 10 minimum wages.

These results may be related to the fact that, as DIEESE (2011), the average monthly income for $53.6 \%$ of the rural workers in Brazil was $\mathrm{R} \$ 795.00$. According to the author, the average monthly income per household in rural areas was $\mathrm{R} \$ 380.00$.

These results may be related to the fact that land access to a wide range of family producers in different production systems, there is a lack of professional training and specialized technical assistance (Camargo and Oliveira, 2012). According to DIEESE (2011), the average monthly income for $53.6 \%$ of the rural workers in Brazil was $\mathrm{R} \$ 795.00$.

The results from Tables 4 and 5 are similar to those obtained by Borges et al. (2013). These researchers found that $100.0 \%$ of the fish farmers who practiced family farming in Western Brazilian Amazon said meet legal obligations of the rural property and $60 \%$ reported to contribute to the conservation of protected environmental areas, in order to consider the welfare and social and environmental development of the rural property (health, recreation and education).

\section{Conclusion}

Based on the information gathered, it was possible to understand the perception of farmers regarding the social and environmental aspects in which they are inserted through the analysis of fundamentals that support the development of socio-environmental education plan, so that the rural population be sensitized and know the problems related to the conservation of flora and fauna.

Models that account for the low-paid work on family farms not fully elucidate the situation found in Brazil. The entrance to the land, in the past and in the present, constitutes the expectation of independence for a population that brought their social design conditioned to the large property or, also in essence, from analogies of work that combined compadrio, consanguinity and companionship.

Agriculture continues to be the foundation of the local development and of the rurality model found. This rurality can join or move away from a peasant model, while the profile of social and with nature similarities, suitable to provoke a cultural and environmental landscape interesting to those who live in the countryside. Only in this way, the family farm can fill multiple roles to ensure its action in a rural sense of transforming a variety of subjects.

\section{Conflict of Interests}

The author(s) have not declared any conflict of interests.

\section{ACKNOWLEDGMENTS}

We thank National Council for Scientific and Technological 
Development (CNPq Brazil) for the financial support, and Federal University of Lavras (UFLA) for allowing the first author to take the post-doctoral stage.

\section{REFERENCES}

Anguita, PM, Azcona AP (2007). Explaining local sustainable development by blend-learning in Ibero-American rural communities. Lat. Am. J. Educ. 41(3):1-12. Available on http://www.rieoei.org/deloslectores/1425leiva.pdf

Barreto, AGOP, Sparovek (2005). Atlas of Rural São Paulo. Piracicaba. School of Agriculture Luiz de Queiroz, São Paulo, Brazil. Available on http://www.nadd.prp.usp.br/cis/detalhebancodados. aspx?cod=b76

Borges AF, Borges MACS, Rezende JLP (2013). Environmental performance of fish farming in the western Brazilian Amazon. J. Glob. Sci. Technol. 6(1):141-152. Available on http://rioverde.ifgoiano.edu.br/periodicos/index.php/gst/article/view/45 9/345

BRAZIL (2006). Law no 11,326, July 24, 2006. Establishes the concept of family agriculture. Official Federal Gazette, Brasília, 24 July, 2006. Available on http://www.planalto.gov.br/ccivil_03/_ato20042006/2006/lei/l11326.htm

Buainain AM, Romeiro AR, Guanziroli C (2003). Family farming and the new rural world. Sociologies, Porto Alegre, Brazil, 10. Available on http://www.scielo.br/scielo.php?script=sci arttext\&pid=s15174522200 3000200011\&lng=pt\&nrm=iso/ Doi: http://dx.doi.org/10.1590/s151745222003000200011

Camargo RAL, Oliveira JTA (2012). Family agriculture, multifunctionality of agriculture and rural life: a complex reality interfaces. Rural Sci. Brazil 42(9).1707-1714 Available on http://www.scielo.br/scielo.php?pid=S0103$84782012000900030 \&$ script=sci_arttext\&tlng=es dx.doi.org/10.1590/s0103-84782012005000068
CEPAL (United Nations Economic Commission for Latin America and the Caribbean) (2012). State of the cities of Latin America and the Caribbean 2012: Towards new transition uma human. Santiago, Chile.

DIEESE (Department of Statistics and Socioeconomic Studies) (2011). Statistics rural 2010-2011. São Paulo: Dieese, 2011. Available on http://www.dieese.org.br/anu/anuariorural/anuariorural10-11.pdf.

Guanziroli CE, Romeiro A, Buainain AM (2009). Family farming and agrarian reform in twenty-first century. Rio de Janeiro, Brazil: Garamond.

Hoffman R, Ney MG (2010). Agrarian structure and agricultural property in Brazil: large regions and states. Brasilia, Brazil: Ministry of Agrarian Development.

IBGE (Brazillian Institute of Geography and Statistics. Census of Agriculture) (2006). Available on www.ibge.gov.br.

IBGE (Population Census 2010) (2010). Available on censo2010.ibge.gov.br

Márquez FD (2001). New horizons in rural development. Madrid: Editions Akal.

Statistics (2011). IBM SPSS 19.0 [program]. Chicago, IL: SPSS.

Waquil PD, Mattos EJ (2002). Income distribution in Rio Grande do Sul: a comparison between rural and urban. FEE, Porto Alegre, Brazil, 23:621-644. 